\title{
Isolation endophytic bacteria from elephant grass (Pennisetum purpureum Schumach) and their potential application
}

\author{
Pham Nu Kieu Diem ${ }^{1}$, Nguyen Ngoc Bao Chau ${ }^{1 *}$, Nguyen Bao Quoc ${ }^{2}$ \\ ${ }^{1}$ Ho Chi Minh City Open University, Vietnam \\ ${ }^{2}$ Nong Lam University Ho Chi Minh City, Vietnam \\ *Corresponding author: chau.nnb@ou.edu.vn
}

\begin{tabular}{|c|c|}
\hline ARTICLE INFO & ABSTRACT \\
\hline $\begin{array}{l}\text { DOI:10.46223/HCMCOUJS. } \\
\text { tech.en.8.2.341.2018 }\end{array}$ & $\begin{array}{l}\text { In this study, } 25 \text { endophytic bacteria were isolated and } \\
\text { purified from the rhizome, stem and leaf of the elephant grass, } \\
\text { which were tested for their biological control properties. The } \\
\text { number of living and dead brown planthoppers was recorded and } \\
\text { the mortality rate was analyzed by using Abbott's formula. The } \\
\text { results indicated that three endophytic bacteria including VBL1, } \\
\text { VBT1 and VBT5 showed the highest biological control of }\end{array}$ \\
\hline Received: February $6^{\text {th }}, 2018$ & Nilaparvata lugens at the mortality rate $46.95 \%, 55.02 \%$ and \\
\hline Revised: April $15^{\text {th }}, 2018$ & $55.02 \%$, respectively after 8 days of screening and the significant \\
\hline Accepted: May $14^{\text {th }}, 2018$ & $\begin{array}{l}\text { difference compared to other isolates }(\mathrm{P}<0.05) \text {. Additionally, } \\
\text { insecticidal activity of three bacterial isolates was conducted at } \\
\text { different concentrations }\left(10^{6}, 10^{7}, 10^{8} \mathrm{CFU} / \mathrm{mL}\right) \text { and we found } \\
\text { that the highest mortality rate of brown planthopper was } \\
\text { significantly observed at } 10^{8} \mathrm{CFU} / \mathrm{mL} \text { for VBL1, VBT1 and } \\
\text { VBT5 isolates after } 10 \text { days trial }(\mathrm{P}<0.05) \text {. Three different isolates }\end{array}$ \\
\hline Keywords: & VBL1, VBT1 and VBT5 were similar to Bacillus pumilus (VBT1 \\
\hline $\begin{array}{l}\text { biological control, endophytic } \\
\text { bacteria, insecticidal activity, } \\
\text { Nilaparvata lugens, Pennisetum } \\
\text { purpurrerum }\end{array}$ & $\begin{array}{l}\text { and VBT5), Bacillus thuringensis (VBL1). This result plays an } \\
\text { important role in understanding endophytic bacteria from elephant } \\
\text { grass for biological control of brown planthopper in the future. }\end{array}$ \\
\hline
\end{tabular}

\section{Introduction}

Endophytes, often a bacterium or fungus, live within a plant for the least part of its life cycle, especially endophytic bacteria and fungi almost have not caused any disease symptoms (Azevedo, Maccheroni, Pereira, \& de Araújo, 2000). Endophytes may enhance host growth by auxin synthesis (IAA) (Barbieri, Zanelli, Galli, \& Zanetti, 1986), pollutant elimination out of host (Rosenblueth \& Martinez-Romero, 2006), nutrient acquisition and may improve the plant's ability to tolerate abiotic stress, enhance resistance to insects (Fahey, Dimock, Tomasino, Taylor, \& Carlson, 1991). Endophytic bacteria can promote plant growth by various mechanisms ( $\mathrm{Li}$ et al., 2016). Recently, diverse endophytic bacteria are now being used worldwide as bio-inoculants to promote plant growth and development under normal and various stresses like heavy metals, herbicides, insecticides, fungicides, and salinity (Ahemad \& Kibret, 2014). Endophytic bacteria enhance the host to withstand pest attack by induced 
systemic resistance (ISR).

Many studies indicated the role of fungal endophytes in grasses nearly a century ago. The Poaceae family is one of the most important families in plants and distributed around the world. Grass of Poaceae family is elephant grass Pennisetum purpureum Schumach (Poaceae), stylo grass (Brachiaria mutica), etc. Four selected endophytic bacterial strains were reported successfully isolated from elephant grass significantly reduced the harmful effects of salt stress, promoted plant growth and biomass yield on hybrid Pennisetum in vitro, which were classified into four bacterial genera such as Sphingomonas, Bacillus, Pantoea, and Enterobacterc. Each of the bacterial strains tested showed at least two or more PGP (plant growth-promoting) properties, the ability of IAA production, siderophore production, nitrogen fixation, ammonia production, inorganic phosphate solubilization, or ACC (1-aminocyclopropane-1-carboxylic acid) deaminase activity ( $\mathrm{Li}$ et al., 2016). In addition, under greenhouse conditions, the endophytic bacteria strains EPCO 102, EPCO 16 and Pf1, which were isolated from cotton plants with chitin treated plants, showed higher growth promotion and reduced pest population. Endophyte-treated plants were greatly promoted plant growth and reduced the Helicoverpa armigera population compared to endosulfan treatment (Rajendran, Samiyappan, Raguchander, \& Saravanakumar, 2007). Endophytes increased tolerance for abiotic and biotic stresses, produce toxins and deterrents that reduce insect herbivory on their host grasses (Takuya \& Koya, 2010). Therefore, the objective of this study was to isolate endophytic bacteria from elephant grass and to determine the susceptibility of brown planthopper to the endophytic bacteria. The investigation would potentially offer an opportunity to exploit some valuable endophytic bacteria as biological control agents.

\section{Materials and methods}

\subsection{Plant material}

Rhizome, stem, leaf from elephant grass was collected from $\mathrm{Cu}$ Chi and Binh Duong province.

\subsection{Isolation of endophytic bacteria}

Rhizome, stem, leaf was washed thoroughly under tap water for $10 \mathrm{~min}$ to remove any adhering soil, dipped in $10 \%$ of commercial bleach (5.25\% available chlorine) for 3 min, then transferred to a $3 \%$ hydrogen peroxide solution for $3 \mathrm{~min}$, and finally rinsed three times with sterilized water. To ascertain that the surface disinfection process was successful, an aliquot of $100 \mu \mathrm{L}$ final wash was inoculated in LB medium for sterility check. Then, tissues were macerated using a mortar and pestle in a small volume of sterile phosphate buffered saline (PBS, $\mathrm{pH}$ 7.4). This suspension was plated on LB medium and incubated at $28^{\circ} \mathrm{C}$ for $48-72 \mathrm{~h}$.

\subsection{Brown plant hopper biological control ability}

Rice seed Nang Hoa 9 sensitive to brown planthoppers and brown planthopper adults were collected from Long An province. Five adults of Nilaparvata lugens were released into 20 days-old rice seedlings, covered by a plastic tube and a muslin cloth. The isolated bacteria strains were cultured in nutrient broth $\left(10^{8} \mathrm{CFU} / \mathrm{mL}\right.$ concentration) and $10 \mathrm{ml}$ bacteria broth was sprayed to the experiment continuously every $24 \mathrm{~h}$ for 3 days. A number of dead brown planthoppers were recorded after 4, 6, 8 days. Each endophytic bacteria isolate was tested with a total of 20 adults of Nilaparvata lugens at $10^{8} \mathrm{CFU} / \mathrm{mL}$ concentration and distilled water was 
used as a control treatment.

\subsubsection{Investigation the optimal concentration of endophytic bacteria}

We selected some bacteria that have the highest biological control, we examined endophytic bacteria at 3 different concentrations $\left(10^{6}, 10^{7}, 10^{8} \mathrm{CFU} / \mathrm{mL}\right)$. Data were recorded after 4, 6, 8, and 10 days. The number of living and dead brown planthoppers were recorded and the mortality rate was analyzed by using Abbott's formula:

$$
E(\%)=\frac{(C-T)}{C} \times 100
$$

E (\%): Efficiency percentage; C: Number of living BPH in the control treatment; T: Number of living BPH in the endophytic treatments.

\subsubsection{Bacterial identification using $16 S$ rRNA sequences}

DNA extraction and PCR amplification of $16 S$ rRNA: The DNA extraction protocol was followed Phuong, Nguyen, and Le (2015). The amount and purity of DNA were determined by absorbance at $260 \mathrm{~nm}$ and $280 \mathrm{~nm}$ using UV-spectrophotometer. The bacterial strains were characterized by $16 \mathrm{~S}$ rRNA gene (rDNA) sequencing analysis. PCR was performed from overnight grown cells using universal primers (63F 5'- CAGGCCTAACACATGCAAGTC -3' and 1489R 5'-TACCTTGTTAFFACTTCA-3') (Julian et al., 1998; Weisburg, Barns, Pelletier, $\&$ Lane, 1991). The amplification was performed in a thermocycler programmed as follows: $95^{\circ} \mathrm{C}$ for $3 \mathrm{~min} ; 34$ cycles of $95^{\circ} \mathrm{C}$ for $30 \mathrm{~s}, 52^{\circ} \mathrm{C}$ for $30 \mathrm{~s}, 72^{\circ} \mathrm{C}$ for $2 \mathrm{~min} ; 72^{\circ} \mathrm{C}$ for $5 \mathrm{~min} ; 4^{\circ} \mathrm{C}$ for storage. The PCR amplicon was purified and sequenced by the VNDAT company (http://vndat.com.vn/vn/). Partial 16S rDNA sequences obtained were analyzed using the BLAST tool on the NCBI website.

\subsection{Statistical analysis}

Data were subjected to analysis of variance (ANOVA) followed by Duncan, Statgraphics plus 3.0 software.

\section{Results and discussion}

\subsection{Endophytic bacteria isolation}

25 endophytic bacteria strains were isolated and purified (Figure.1 and Figure.2). The isolated bacterial strains were tested by Gram staining and spore staining (Table 1).

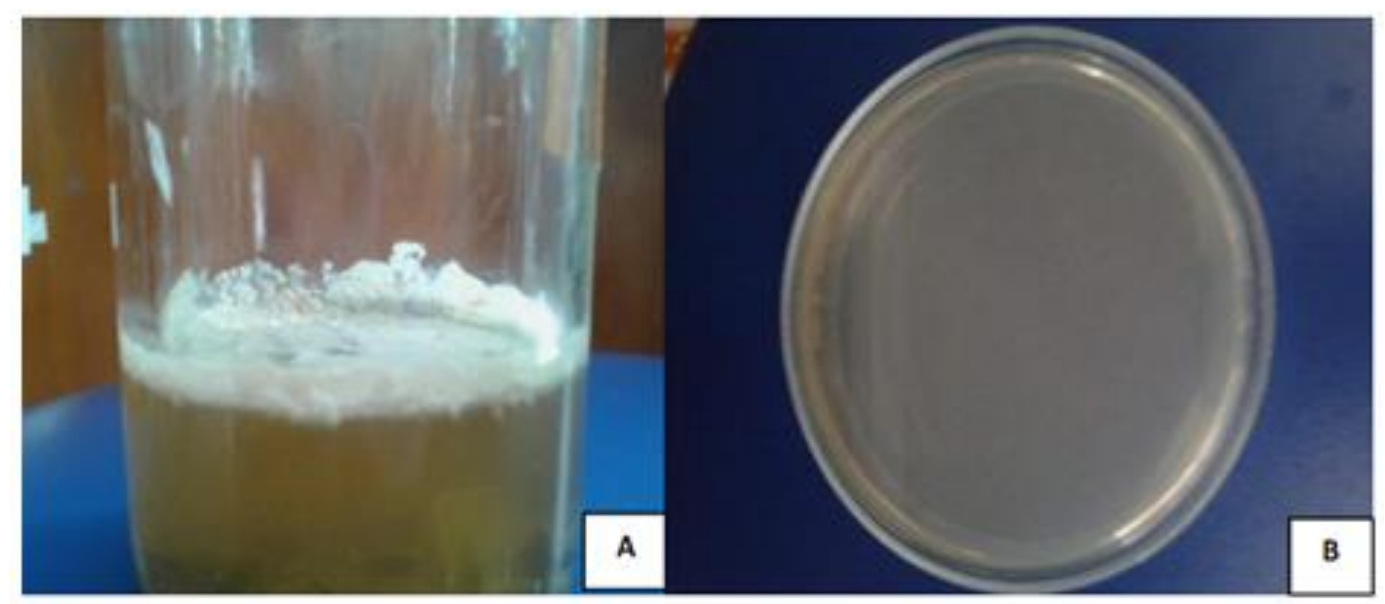


Figure 1. Soaking in TSB (A) and TSA control (B)

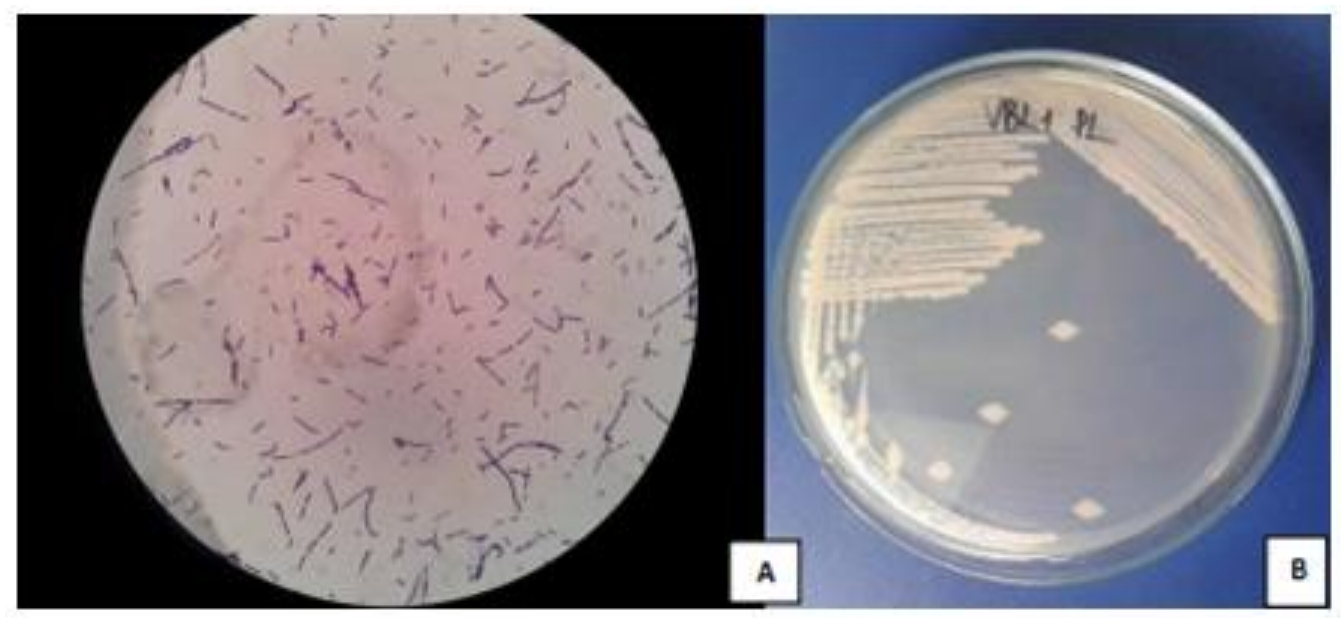

Figure 2. VBL1

\section{Table 1}

Stainning results of the endophytic bacteria isolates

\section{Collection}

$$
\text { place }
$$

No.

Strains

Gram staining

Spore stain

\begin{tabular}{|c|c|c|c|c|}
\hline & 1 & VCT1 & Gram (+) & + \\
\hline & 2 & VCT2 & Gram (-) & - \\
\hline & 3 & VCT3 & $\operatorname{Gram}(+)$ & + \\
\hline & 4 & VCT4 & $\operatorname{Gram}(+)$ & + \\
\hline & 5 & VCT5 & Gram (+) & + \\
\hline Cu Chi-HCM & 6 & VCT6 & Gram (-) & - \\
\hline & 7 & VCL1 & Gram (-) & - \\
\hline & 8 & VCL2 & Gram (+) & + \\
\hline & 9 & VCR1 & Gram (-) & - \\
\hline & 10 & VCR2 & Gram (-) & - \\
\hline & 11 & VCR3 & Gram (-) & - \\
\hline & 12 & VCR4 & Gram (-) & \\
\hline
\end{tabular}




\begin{tabular}{|c|c|c|c|c|}
\hline $\begin{array}{c}\text { Collection } \\
\text { place }\end{array}$ & No. & Strains & Gram staining & Spore stain \\
\hline \multirow{13}{*}{$\begin{array}{l}\text { Binh Duong } \\
\text { province }\end{array}$} & 13 & VBT1 & Gram (-) & - \\
\hline & 14 & VBT2 & $\operatorname{Gram}(+)$ & + \\
\hline & 15 & VBT3 & Gram (+) & + \\
\hline & 16 & VBT4 & Gram (+) & + \\
\hline & 17 & VBT5 & Gram (+) & + \\
\hline & 18 & VBT6 & Gram (+) & + \\
\hline & 19 & VBT7 & Gram (+) & + \\
\hline & 20 & VBL1 & Gram (+) & + \\
\hline & 21 & VBL2 & Gram (+) & + \\
\hline & 22 & VBL3 & Gram (+) & + \\
\hline & 23 & VBL4 & Gram (+) & + \\
\hline & 24 & VBR1 & Gram (-) & + \\
\hline & 25 & VBR2 & Gram (+) & + \\
\hline
\end{tabular}

Note: Note: Positive results: + Negative results: -

Source: Data analysis result of the researc

3.2. The optimal concentration of endophytic inoculants to control brown planthopper

Table 2 indicated that the 3 isolated strains, including VBL1, VBT1 and VBT5, showed the highest biological control brown planthopper at the mortality rate 46,95\%; 55,02\% and $55,02 \%$, respectively after 8 days trial and have significant difference compare to other treatments $(\mathrm{P}<0.05)$. 


\section{Table 2}

Biological control brown planthoppers of endophytic bacteria isolates

\begin{tabular}{|c|c|c|c|}
\hline \multirow{2}{*}{ Isolates } & \multicolumn{3}{|c|}{ Days after treatments } \\
\hline & 4 days & 6 days & 8 days \\
\hline VBT5 & $17,74 \mathrm{a}$ & $43,10 \mathrm{a}$ & $55,02 \mathrm{a}$ \\
\hline VBL1 & $8,89 \mathrm{a}$ & $26,58 \mathrm{ab}$ & $46,95 \mathrm{ab}$ \\
\hline VBL2 & $0,05 \mathrm{a}$ & $26,58 \mathrm{ab}$ & $43,10 a b c$ \\
\hline VBR2 & 8,89 a & $26,58 \mathrm{ab}$ & $30,80 \mathrm{bcd}$ \\
\hline VBT1 & 8,89 a & $26,58 \mathrm{ab}$ & $55,02 \mathrm{a}$ \\
\hline VCR1 & 8,89 a & $17,74 \mathrm{bc}$ & $30,80 \mathrm{bcd}$ \\
\hline VBT3 & 8,89 a & $17,74 \mathrm{bc}$ & $26,56 \mathrm{bcde}$ \\
\hline VCT5 & $0,05 \mathrm{a}$ & $17,74 \mathrm{bc}$ & 26,18 cde \\
\hline VCT6 & 8,89 a & $17,74 \mathrm{bc}$ & $17,74 \mathrm{def}$ \\
\hline VCL1 & 8,89 a & $17,74 \mathrm{bc}$ & $26,58 \mathrm{bcde}$ \\
\hline VBL4 & $0,05 \mathrm{a}$ & 8,89 bc & 8,89 ef \\
\hline VBT2 & $0,05 \mathrm{a}$ & 8,89 bc & 8,89 ef \\
\hline VCR3 & $0,05 \mathrm{a}$ & 8,89 bc & 8,89 ef \\
\hline VCT1 & 8,89 a & 8,89 bc & 8,89 ef \\
\hline VCT2 & $0,05 \mathrm{a}$ & 8,89 bc & $17,74 \mathrm{def}$ \\
\hline VBR1 & $0,05 \mathrm{a}$ & 8,89 bc & 26,56 bcde \\
\hline VCL2 & $0,05 \mathrm{a}$ & 8,89 bc & 8,89 ef \\
\hline VBL3 & $0,05 \mathrm{a}$ & $0,05 \mathrm{c}$ & 26,56 bcde \\
\hline VBT4 & 8,89 a & $0,05 \mathrm{c}$ & $0,05 \mathrm{f}$ \\
\hline VCR2 & $0,05 \mathrm{a}$ & $0,05 \mathrm{c}$ & $0,05 \mathrm{f}$ \\
\hline VCR4 & $0,05 \mathrm{a}$ & $0,05 \mathrm{c}$ & 8,89 ef \\
\hline VCT3 & $0,05 \mathrm{a}$ & $0,05 \mathrm{c}$ & $0,05 \mathrm{f}$ \\
\hline VBT6 & $0,05 \mathrm{a}$ & $0,05 \mathrm{c}$ & $0,05 \mathrm{f}$ \\
\hline VCT4 & $0,05 \mathrm{a}$ & $0,05 \mathrm{c}$ & $0,05 \mathrm{f}$ \\
\hline VBT7 & $0,05 \mathrm{a}$ & $0,05 \mathrm{c}$ & 8,89 ef \\
\hline
\end{tabular}

Note: Data were analyzed using one- way analysis of variance (ANOVA) followed by Duncan. Different letters indicate statistically significant differences among groups $(\mathrm{p}<0.05)$

Source: The researcher's data analysis

\section{Table 3}

Investigation of the optimal concentration of three endophytic bacteria isolates

\begin{tabular}{|c|c|c|c|c|c|}
\hline \multirow{2}{*}{ Isolates } & $\begin{array}{c}\text { CFU/ml } \\
\text { concentration }\end{array}$ & \multicolumn{4}{|c|}{ Days after treatments } \\
\cline { 3 - 6 } & VBT5 & $\mathbf{4}$ days & 6 days & $\mathbf{8}$ days & $\mathbf{1 0}$ days \\
\hline & $10^{8}$ & $29,24 \mathrm{a}$ & $36,23 \mathrm{a}$ & $47,97 \mathrm{a}$ & $60,14 \mathrm{a}$ \\
\cline { 3 - 6 } & $10^{7}$ & $4,62 \mathrm{~b}$ & $27,86 \mathrm{a}$ & $39,18 \mathrm{~b}$ & $49,35 \mathrm{~b}$ \\
\hline
\end{tabular}




\begin{tabular}{|c|c|c|c|c|c|}
\hline \multirow{2}{*}{ Isolates } & $\begin{array}{c}\text { CFU/ml } \\
\text { concentration }\end{array}$ & \multicolumn{4}{|c|}{ Days after treatments } \\
\cline { 3 - 6 } & $10^{6}$ & $\mathbf{4}$ days & 6 days & $\mathbf{8}$ days & $\mathbf{1 0 ~ d a y s}$ \\
\hline \multirow{2}{*}{ VBT1 } & $10^{8}$ & $24,54 \mathrm{a}$ & $37,74 \mathrm{a}$ & $50,85 \mathrm{a}$ & $63,83 \mathrm{a}$ \\
\hline & $10^{7}$ & $13,83 \mathrm{ab}$ & $26,57 \mathrm{~b}$ & $37,68 \mathrm{~b}$ & $49,35 \mathrm{~b}$ \\
\hline & $10^{6}$ & $4,62 \mathrm{~b}$ & $9,23 \mathrm{c}$ & $28,24 \mathrm{c}$ & $40,69 \mathrm{c}$ \\
\hline & $10^{8}$ & $24,54 \mathrm{a}$ & $39,10 \mathrm{a}$ & $50,74 \mathrm{a}$ & $61,80 \mathrm{a}$ \\
\hline & $10^{7}$ & $13,83 \mathrm{~b}$ & $26,57 \mathrm{~b}$ & $42,13 \mathrm{~b}$ & $52,30 \mathrm{~b}$ \\
\hline & $10^{6}$ & $0,02 \mathrm{c}$ & $19,44 \mathrm{c}$ & $31,56 \mathrm{c}$ & $42,13 \mathrm{c}$ \\
\hline
\end{tabular}

Note: Data were analyzed using one-way analysis of variance (ANOVA) followed by Duncan. Different letters indicate statistically significant differences among groups $(\mathrm{p}<0.05)$

Source: The researcher's data analysis

The result of the investigation of the optimal concentration of three endophytic bacteria isolates (VBL1, VBT1 and VBT5) showed the highest biological control Nilaparvata lugens after 10 days of treatments at $10^{8} \mathrm{CFU} / \mathrm{ml}$ concentration (Table 3). Endophytic bacteria offers an effective strategy for the biological control of the pest. Several endophytic bacterial strains have been reported to induce systemic resistance such as ISR (induced systemic resistance), bioagents promote plant growth and reduce pest in several crops. More than 30 species of insect have been found to be combined with endophyte infected Lolium perenne and Lolium arundinaceum, or by bioassaying the compounds produced by the endophyte in those plants; however, insect species will respond differently to endophyte-infected grass (Takuya \& Koya, 2010). Although we have not examined in detail the biological role of 3 endophytic bacteria isolates in this study but the result showed the capacity of the three endophytic bacteria isolates (VBL1, VBT1 and VBT5) to control the brown planthoppers.

\subsection{Molecular identification of effective bacterial endophytes}




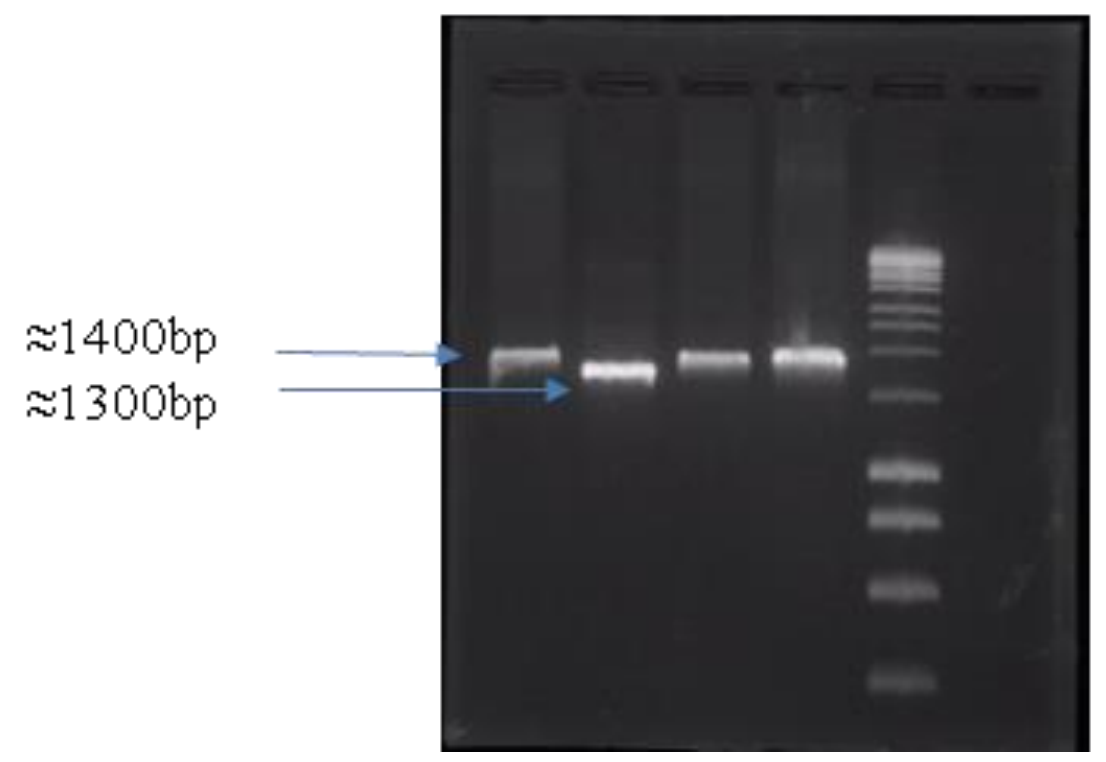

Figure 3. PCR amplification of single $1.5 \mathrm{~kb}$ of $16 \mathrm{~S}$ rDNA amplicon16S rDNA gene on an agarose gel (1\%). Lane 1: VBT1 isolate- 1.4kb DNA; Lane 2: VBL5 isolate-1.3kb DNA; Lane 3, 4: VBL1-1.4 lb; Lane 5: DNA marker (1kb ladder)

The $16 \mathrm{~S}$ rDNA primers amplied a fragment size of $1.4 \mathrm{~kb}$ and $1.3 \mathrm{~kb}$. We compared the sequence of each strain VBL1, VBT1 and VBT5 on NCBI genebank and the variable sites analyses from the alignment of the dataset were performed in MEGA 6.06. Maximum Likelihood (ML) method was used to reconstruct phylogenetic trees with value Bootstrap 1000 repeat times. The result of identification was similar to Bacillus pumilus (VBT1, VBT5) and Bacillus thuringensis (VBL1) (Figure 4). A study by Li et al. (2016) revealed the four endophytic bacteria from elephant grass which were classified into four bacterial genera: Sphingomonas, Pantoea, Bacillus, and Enterobacter significantly promoted plant growth and biomass yield, alleviated the harmful effects of salt stress on Hybrid Pennisetum. Another study on the control of insect-pests by endophytic fungi showing protection of the perennial ryegrass Lolium perenne L. against the sod webworm (Funk et al., 1983, Kanda, Hirai, Koga, \& Hasegawa, 1994). Also, Gaynor and Hunt (1983) observed in several ryegrasses that high fungi infection is correlated with a decrease in the attack frequency of the Argentine steem weevil Listronotus bonariensis. 


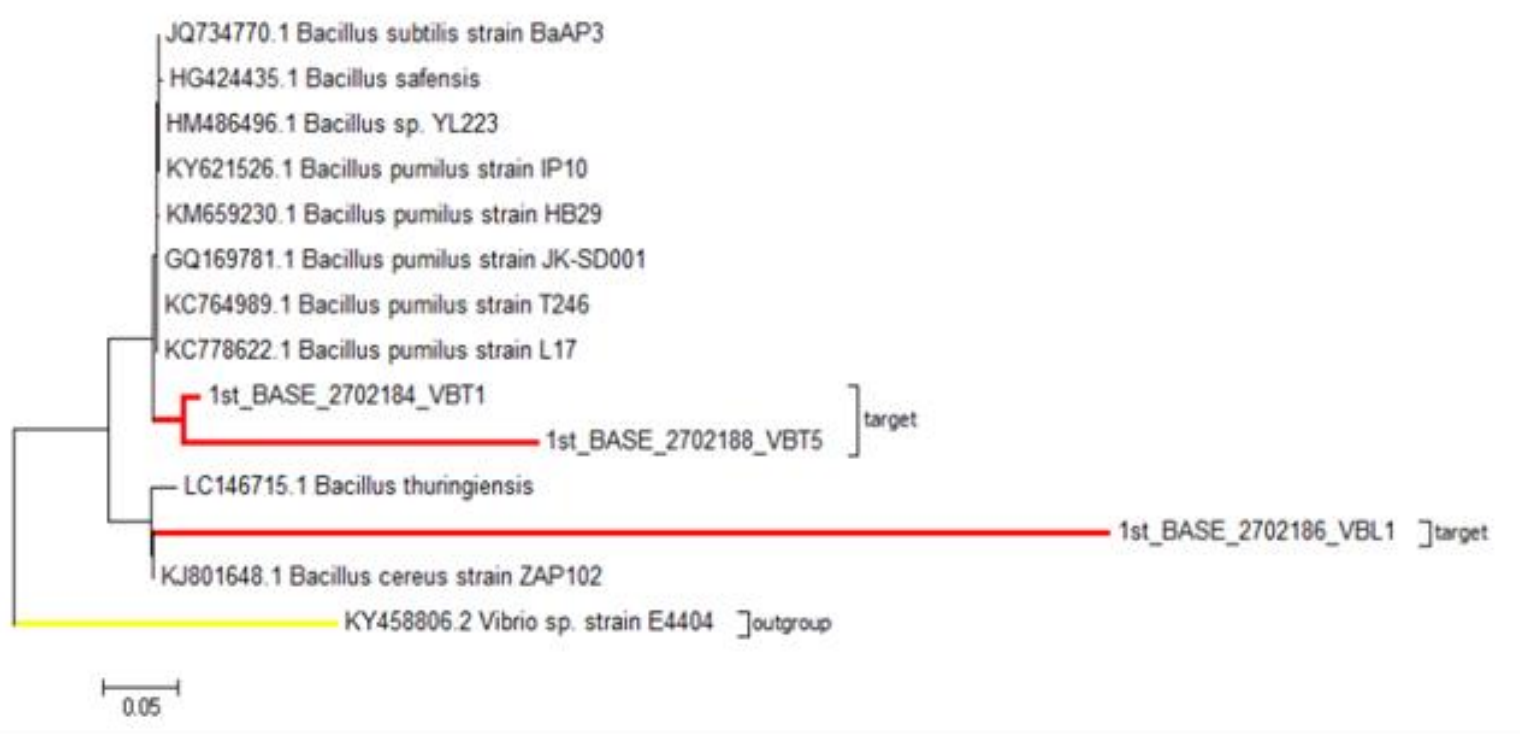

Figure 4. Maximum Likelihood tree of bacteria endophytes on 16S rRNA gene sequences

\section{Conclusion}

In this study, we isolated 25 endophytic bacteria strains and selected three endophytic bacteria strains (VBL1, VBT1 and VBT5) which showed the highest biological control to brown planthopper. Additionally, the concentration of $10^{8} \mathrm{CFU} / \mathrm{mL}$ is the optimal concentration in pesticide activity of these strains. Therefore, this result contributed important data for the collection of endophytic bacteria and provided the potential to control brown planthopper in the future.

\section{ACKNOWLEDGEMENTS}

The authors would like to acknowledge Ho Chi Minh City Open University for Student research grant to Pham Nu Kieu Diem.

\section{References}

Ahemad, M., \& Kibret, M. (2014). Mechanisms and applications of plant growth promoting rhizobacteria: Current perspective. Journal of King Saud University Science, 26, 11-20.

Arunachalam, K., Sathyanarayanan, K., Darshan, B., \& Raja, R. (2010). Studies on the characterisation of bioselant properties of Bacillus sphaericus. International Journal of Engineering Science and Technology, 2, 270-277.

Azevedo, J. L., Maccheroni, W., Jr., Pereira, J. O., \& de Araújo, W. L. (2000). Endophytic microorganisms: A review on insect control and recent advances on tropical plants. $E J B$ Electronic Journal of Biotechnology, 3(1), 40-65.

Bandara, W. M. M. S., Seneviratne, G., \& Koolasooriya, S. A. (2006). Interaction among endophytic bacteria and fungi: Effects and potentials. Journal of Biosciences, 31, 645650 . 
Barbieri, P., Zanelli, T., Galli, E., \& Zanetti, G. (1986). Wheat inoculation with Azpspirillum brasilense Sp6 and some mutants altered in nitrogen fixation and indole-3-acetic acid production. FEMS Microbiology, 36, 87-90.

Barrow, G. I., \& Feltham, R. K. A. (1993). Cowan and Steel's manual for the identification of medical bacteria. Cambridge, UK: Cambridge University Press.

Breen, J. P. (1994). Acremonium endophyte interactions with enhanced plant resistance to insects. Annual Review of Entomology, 39, 401-423.

Clay, K. (1988a). Fungal endophytes of grasses. A defensive mutalism between plants and fungi. Ecology, 69, 10-16.

Clay, K. (1988b). Fungal endophytes of grasses their potential as biocontrol agents. Mycological Research, 92, 1-12.

Clay, K. (1989). Clavicipitaceous endophytes of grasses their potential as biocontrol agents. Mycological Research, 92, 1-12.

Claydon, N., Grove, J. F., \& Pople, M. (1985). Elm bark beetle boring and feeding deterrents from Phomopsis ablonga. Phytochemistry, 2, 937-943.

Demirel, R., Sariozlu, N. Y., \& Ilhan, S. (2013). Polymerase chain reaction (PCR) identification of terverticillate Penicillium species isolated from agricultural soils in eskishir province. Brazilian Archives of Biology and Technology, 56(6), 980-984.

Fahey, J. W., Dimock, M. B., Tomasino, S. F., Taylor, J. M., \& Carlson, P. S. (1991). Genetically engineered endophytes as biocontrol agents: A case study from industry. In Microbiol ecology of leaves (pp. 401-411). London, United Kingdom: Springer - Verlag.

Fernando, H. Y., Elikewela, Y., De Alwis, H. M., Senadheera, D., \& Kudagamage, C. (1977). Varietal resistance to the brown planthopper Nilaprvala lugens. In Brown planthopper: Threat to rice production in Asia. Los Banos, Philippines: International Rice Research Institute.

Funk, C. R. R., Halisky, P. M., Johnson, M. C., Siegel, M. R., Stewart, A. V., Ahmad, S., ... Harvey, I. C. (1983). An endophytic fungus and resistance to sod webworms: Associations in Lolium perenne. Bio/Techonology, 1, 189-191.

Gaynor, D. L., \& Hunt, W. F. (1983). The relationship between nitrogen supply, endophytic fungus and Argentine sterm weevil resistance in ryegrass. Proceedings of the New Zealand Grassland Association, 44, 257-263.

Hinckley, A. D. (1963). Ecology and control of rice planthopper in Fiji, Bull. Entomological Research, 54, 467-481.

Julian, R. M., Sato, T., Weightman, A. J., Martin, T. A., Fry, J. C., Hiom, S. J., \& Wade, W. G. (1998). Design and evaluation of useful bacterium-specific PCR primers that amplify genes coding for bacterial 16S rRNA. Apply Environmental Microbiology, 64(2), 795799.

Kanda, K., Hirai, Y., Koga, H., \& Hasegawa, K. (1994). Endophyte-enhanced resistance in perennial ryegrass and tall fescue to bluegrass webworm. Japanese Journal of Applied Entomology and Zoology, 38, 141-145. 
Li., X., Geng, X., Xie, R., Fu, L., Jiang, J., Gao, L., \& Sun, J. (2016). The endophytic bacteria isolated from elephant grass (Pennisetum purpureum Schumach) promote plant growth and enhance salt tolerance of Hybrid Pennisetum. Biotechnology Biofuels, 9, 1-12.

Mendpara, J., Parekh, V., Vaghela, S., Makasana, A., Kunjadia, D. P., Sanghvi, G., ... Dave, G. S. (2013). Isolation and characterization of high salt tolerant bacteria from agricultural soil. European Journal of Experimental Biology, 3(6), 351-358.

Phuong, T. K., Nguyen, N. T., \& Le, T. H. A. (2015). Isolation and identification of some Lactobacillus sp. strain from traditional fermented foods. Journal of Science Ho Chi Minh City Open University, 1(13), 21-29.

Rajendran, L., Samiyappan, R., Raguchander, T., \& Saravanakumar, D. (2007). Endophytic bacteria mediate plant resistance against cotton bollworm. Journal of Plant Interactions, 2(1), 1-10.

Rosenblueth, M., \& Martinez-Romero, E. (2006). Bacterial endophytes and their interactions with hosts. The American Phytopathological Society, 19, 827-837.

Takuya, S., \& Koya., S. (2010). Inhibitory effect of an endophytic fungus, Neotyphodium lolii, on the feeding and survival of Ostrinia furnacalis (Guenee) (Lepidoptera: Pyralidae) and Sesamia inferens (Walker) (Lepidoptera: Noctuidae) on infected Lolium perenne. Applied Entomology and Zoology, 45, 225-231.

Weisburg, W. G., Barns, S. M., Pelletier, D. A., \& Lane, D. J. (1991). 16S ribosomal DNA amplification for phylogenetic study. Journal of Bacteriology, 173(2), 697-703. 